\title{
Expression of inducible nitric oxide synthase is increased in patients with heart failure due to ischemic disease
}

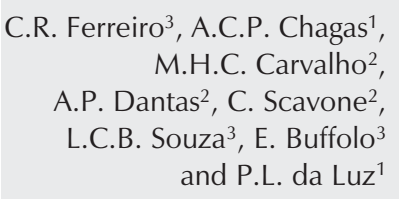

\author{
${ }^{1}$ Unidade de Aterosclerose, Instituto do Coração (Incor), Hospital das Clínicas, \\ Faculdade de Medicina, Universidade de São Paulo, São Paulo, SP, Brasil \\ ${ }^{2}$ Departamento de Farmacologia, Instituto de Ciências Biomédicas, \\ Universidade de São Paulo, São Paulo, SP, Brasil \\ ${ }^{3}$ Hospital do Coração, Associação do Sanatório Sírio,São Paulo, SP, Brasil
}

\section{Correspondence \\ P.L. da Luz \\ Unidade de Ateroscleroses \\ Incor, HC, FM, USP \\ Av. Dr. Enéas C. Aguiar, 44 \\ 0540-3000 São Paulo, SP \\ Brasil \\ Fax: +55-11-3069-5547 \\ E-mail: daluzp@incor.usp.br}

Publication supported by FAPESP.

Received February 24, 2003

Accepted April 7, 2004

\begin{abstract}
The objective of the present study was to determine the relationship between nitric oxide synthases (NOS) and heart failure in cardiac tissue from patients with and without cardiac decompensation. Right atrial tissue was excised from patients with coronary artery disease (CAD) and left ventricular ejection fraction (LVEF) $<35 \%(\mathrm{~N}=10)$, and from patients with CAD and $\mathrm{LVEF}>60 \%(\mathrm{~N}=10)$ during cardiac surgery. NOS activity was measured by the conversion of L-[ $\left[\mathrm{H}^{3}\right]-$ arginine to $\mathrm{L}-\left[\mathrm{H}^{3}\right]$-citrulline. Gene expression was quantified by the competitive reverse transcription-polymerase chain reaction. Both endothelial NOS (eNOS) activity and expression were significantly reduced in failing hearts compared to non-failing hearts: $0.36 \pm 0.18 \mathrm{vs}$ $1.51 \pm 0.31 \mathrm{pmol} \mathrm{mg}^{-1} \mathrm{~min}^{-1}(\mathrm{P}<0.0001)$ and $0.37 \pm 0.08$ vs $0.78 \pm$ 0.09 relative cDNA absorbance at $320 \mathrm{~nm}(\mathrm{P}<0.0001)$, respectively. In contrast, inducible NOS (iNOS) activity and expression were significantly higher in failing hearts than in non-failing hearts: $4.00 \pm$ 0.90 vs $1.54 \pm 0.65 \mathrm{pmol} \mathrm{mg}^{-1} \mathrm{~min}^{-1}(\mathrm{P}<0.0001)$ and $2.19 \pm 0.27$ vs $1.43 \pm 0.13$ cDNA absorbance at $320 \mathrm{~nm}(\mathrm{P}<0.0001)$, respectively. We conclude that heart failure down-regulates both eNOS activity and expression in cardiac tissue from patients with LVEF $<35 \%$. In contrast, iNOS activity and expression are increased in failing hearts and may represent an alternative mechanism for nitric oxide production in heart failure due to ischemic disease.
\end{abstract}

Key words - Nitric oxide synthase

- Left ventricle ejection fraction

- Heart failure

\section{Introduction}

Nitric oxide (NO) is an important cellular signaling molecule (1-5) synthesized by three different isoforms of the enzyme nitric oxide synthase (NOS). Two isoforms are constitutively expressed while one is induced in response to cytokines and endotoxins among other stimuli (6-10).
The pivotal role of endothelium-derived $\mathrm{NO}$ in the regulation of vasomotor tone has been well established, but the impact of NO on cardiac function has only recently been recognized. There is increasing evidence that alterations in NO synthesis are of pathological importance in heart failure. Removal of endocardium or endothelium has been shown to modulate cardiac contraction (11). More- 
over, exposure of cardiac muscle to cytokines impairs cardiac contractility, an effect that seems to be mediated by NO (12). In patients with heart failure, the functional significance of modified myocardial expression of NOS for left ventricular performance remains unclear (13). Studies carried out to investigate the relationship between NOS activity, gene expression and heart failure using myocardial biopsies are controversial. de Belder et al. (14) reported increased myocardial activity of the inducible NOS isoform (iNOS) in patients with dilated cardiomyopathy, but not in ischemic or valvular disease. Thoenes et al. (15) found immunoreactive iNOS protein only in septic hearts, but not in other forms of cardiomyopathy. Others demonstrated iNOS mRNA and immunoreactivity in hearts from patients with dilated cardiomyopathy (16-18), but also in ischemic and valvular disease (16). Conflicting results have also been reported regarding the endothelial isoform (eNOS). Some studies have suggested that eNOS expression and activity are reduced in the failing human heart, while others have observed increased levels $(19,20)$.

The purpose of the present investigation was to examine the activity and gene expression of eNOS and iNOS in atrial tissue from patients with coronary artery disease (CAD), with and without heart failure, who were subjected to cardiac surgery. The specific goal was to assess the relationship between enzymatic activity and left ventricular ejection fraction (LVEF).

\section{Patients and Methods}

\section{Patients}

Twenty consecutive patients with CAD submitted to coronary angiography before cardiac surgery were divided into two groups: A, 10 patients with LVEF $>60 \%$, and $\mathrm{B}, 10$ patients with $\mathrm{LVEF}<35 \%$.

In group $\mathrm{A}$ there were 8 smokers, 8 pa- tients were whites and 2 blacks. In this group, surgery consisted of isolated by-pass grafts in all patients. Exclusion criteria were: previous myocardial infarction, previous cardiac surgery, diabetes mellitus, use of angiotensin-converting enzyme (ACE) inhibitors and/or B-blockers. In group B all patients had previous myocardial infarction, 6 patients had diabetes mellitus and 8 were smokers, and there were 7 whites and 3 blacks. Surgeries in this group were: by-pass grafts plus left ventricular aneurysmectomy in 4 patients, left ventricular remodeling (modified Baptista's surgery) in 4, and isolated bypass in 2. In this group atrial fibrillation was the only exclusion criterion. For ethical reasons, heart failure therapy was maintained and consisted of ACE inhibitors $(\mathrm{N}=9)$, diuretics $(\mathrm{N}=8)$, digitalis $(\mathrm{N}=8)$, and $\mathrm{B}$ blockers $(\mathrm{N}=4)$. All patients were operated upon under extracorporeal circulation.

\section{Methods}

All patients gave written informed consent to participate in the study before the procedure. The protocol was approved by the Human Subjects Review Committee of Hospital do Coração, São Paulo. The investigation was carried out according to the principles outlined in the Declaration of Helsinki.

Left ventricular angiograms and Doppler echocardiography were used to measure LVEF by the area-length method and Simpson's method (21), respectively. Hemodynamic data were obtained 1-4 weeks before cardiopulmonary by-pass. Heart rate was recorded by direct monitoring with a Hewlett Packard device (Handover, MS, USA) and arterial blood pressure was obtained by a direct invasive method using a pressure transducer (HP-104).

In all patients, the right atrial appendage (30 mg) was excised before cardiopulmonary by-pass, and immediately frozen in liquid nitrogen and stored at $-80^{\circ} \mathrm{C}$ for subse- 
quent biochemical analysis.

\section{Measurement of NOS activity}

NOS activity was measured in supernatants from right atrial tissue as described by McKee et al. (22). The NOS assay is based on the biochemical conversion of L-arginine to L-citrulline by NOS. The tissue was homogenized in ice-cold Tris-HCl buffer (20 $\mathrm{mM}$ Tris- $\mathrm{HCl}, 10 \mathrm{mM}$ EDTA, and $10 \mathrm{mM}$ EGTA, pH 7.4) using a Teflon homogenizer. Each homogenate was centrifuged at 12,000 $g$ for $5 \mathrm{~min}$ at $4^{\circ} \mathrm{C}$. Supernatants were removed and the NOS assay was performed by incubation $\left(37^{\circ} \mathrm{C}\right.$ for $\left.60 \mathrm{~min}\right)$ of $100 \mu \mathrm{g}(20$ $\mu \mathrm{l})$ of protein in a final volume of $60 \mu \mathrm{l}$ of assay mixture containing $50 \mathrm{mM}$ Tris- $\mathrm{HCl}, 6$ $\mu \mathrm{M}$ tetrahydrobiopterin, $2 \mu \mathrm{M}$ FAD, $2 \mu \mathrm{M}$ FMN + $10 \mathrm{mM}$ NADPH, $100 \mathrm{mM}$ L-arginine/L-[H $\left[\mathrm{H}^{3}\right]$-arginine $(5 \mu \mathrm{Ci} / \mathrm{ml}), 6 \mathrm{mM}$ $\mathrm{CaCl}_{2}$, and $0.1 \mu \mathrm{M}$ calmodulin. For iNOs activity (calcium/calmodulin-free activity) EDTA/EGTA were added and $\mathrm{CaCl}_{2}$ and calmodulin were omitted. Calcium-dependent (eNOS) activity was calculated as the difference between the calcium-calmodulim sample and the EDTA/EGTA sample. The reaction was stopped with $400 \mu \mathrm{l}$ of ice-cold stop buffer (50 mM HEPES and $5 \mathrm{mMEDTA}$, $\mathrm{pH} 5.5)$ and $100 \mu \mathrm{l}$ of cation-exchange resin (Dowex, $\mathrm{Na}^{+}$form, equilibrated with $50 \mathrm{mM}$ HEPES, $\mathrm{pH}$ 5.5) was added to each reaction mixture to remove excess $\mathrm{L}$ - $\left[\mathrm{H}^{3}\right]$-arginine. The aliquots were placed in spin cups and centrifuged for $1 \mathrm{~min}$ at $12,000 \mathrm{~g}$. The supernatants were collected into vials, scintillation liquid (4 $\mathrm{ml})$ was added and radioactivity was quantified. Samples of rat cerebellum were analyzed simultaneously as a positive control. Protein concentrations in samples of human right atrium homogenates were determined by the Bradford Coomassie brilliant blue method (23) with bovine serum albumin as the standard and homogenization buffer as the blank. This method does not allow separation of neuronal and endothelial components of NOS. Because the neuronal component is probably small and mRNA assessment is specific for eNOS (see ahead), we refer to the activity here as eNOS.

\section{Determination of NOS expression by RT-PCR}

Total cellular RNA was isolated from human right atrium using TRizol Reagent (Gibco-BRL, Life Technologies, Rockville, MD, USA). After DNA digestion (RQ1 DNAse RNAse-free; Promega Corporation, Madison, WI, USA), $1 \mu \mathrm{g}$ total RNA from each preparation was reverse transcribed in the presence of an RNAse inhibitor (RNasIn ${ }^{\circledR}$, Promega Corporation) in a $20-\mu l$ reaction volume containing $50 \mathrm{mM}$ Tris- $\mathrm{HCl}, \mathrm{pH} 8.3$, $75 \mathrm{mM} \mathrm{KCl}, 3.0 \mathrm{mM} \mathrm{MgCl} 2,10 \mathrm{mM}$ dithiothreitol, $2.0 \mathrm{mM}$ deoxynucleotidetriphosphates (dNTP), $200 \mathrm{U}$ of Moloney murine leukemia virus reverse transcriptase (GibcoBRL) and $1 \mu \mathrm{g}$ of oligo (dT)12-18 primer. The reaction was carried out at room temperature for $10 \mathrm{~min}$ and at $37^{\circ} \mathrm{C}$ for $60 \mathrm{~min}$ and stopped by heating at $100^{\circ} \mathrm{C}$ for $5 \mathrm{~min}$. The reverse-transcribed cDNA ( $2 \mu \mathrm{l})$ was amplified in a final volume of $50 \mu \mathrm{l}$ by PCR under standard conditions $\left(1.5 \mathrm{mM} \mathrm{MgCl}_{2}, 450\right.$ $\mu \mathrm{M}$ dNTP, $2.5 \mathrm{U}$ Taq polymerase) with specific primers for human eNOS, iNOS and rat glyceraldehyde-3-dehydrogenase (GAPDH) designed on the basis of published cDNA sequences (24). GAPDH was used as an internal control for co-amplification.

In order to identify optimal amplification conditions, a series of pilot studies were performed using a thermal cycler with a temperature gradient at the annealing step (Eppendorf Mastercycler gradient, Eppendorf-Netheler-Hinz, Hamburg, Germany), various amounts of RT products from 2 to 200 ng RNA, and 20-35 cycles of PCR amplification. Primers and experimental conditions for RT-PCR are summarized in Table 1. Amplification was carried out using an initial denaturing cycle at $94^{\circ} \mathrm{C}$ for 5 min, 
followed by denaturation for $30 \mathrm{~s}$ at $94^{\circ} \mathrm{C}$, annealing (as described in Figure 1), and extension for $45 \mathrm{~s}$ at $72^{\circ} \mathrm{C}$. PCR products $(10$ $\mu l$ per lane) were electrophoresed on $1 \%$
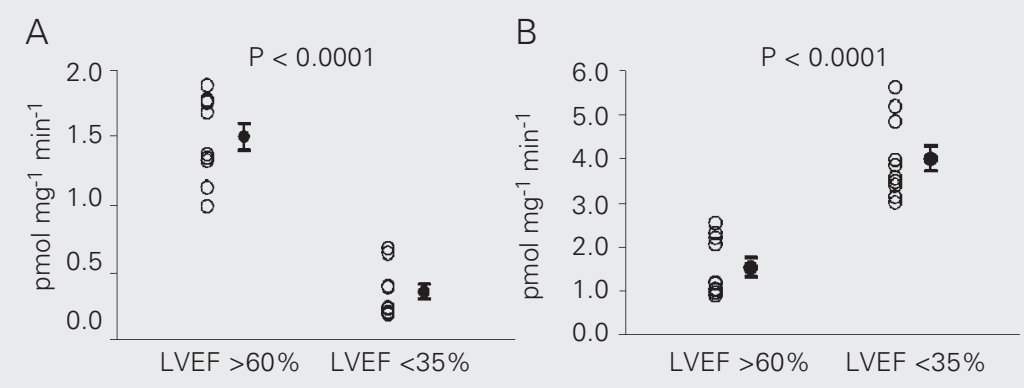

Figure 1. Individual values of (A) endothelial and (B) inducible nitric oxide synthase (NOS) activity in the right atrial appendage of patients in the groups with left ventricular ejection fraction (LVEF) $>60 \%$ and LVEF $<35 \%$. The symbols to the right of individual values are the mean \pm SEM. $N=10$ patients in each group.

Table 1. Primers and experimental conditions used for the determination of NOS expression by RT-PCR.

\begin{tabular}{|c|c|c|c|}
\hline Target gene & Sequences $\left(5^{\prime} \rightarrow 3^{\prime}\right)$ & $\begin{array}{c}\text { Annealing } \\
\text { temperature }\left({ }^{\circ} \mathrm{C}\right)\end{array}$ & $\begin{array}{l}\text { Number } \\
\text { of cycles }\end{array}$ \\
\hline eNOS & $\begin{array}{l}\text { CCAGCTAGCCAAAGTCACCAT (S) } \\
\text { GTCTCGGAGCCATACAGGATT (AS) }\end{array}$ & 55 & 35 \\
\hline iNOS & $\begin{array}{l}\text { GAGGAAGTGGGCAGGAGAATG (S) } \\
\text { GTAGTAGAAAGGGGACAGGAC (AS) }\end{array}$ & 50 & 35 \\
\hline GAPDH & $\begin{array}{l}\text { GTGAAGGTCGGTGTGAACGGATTT (S) } \\
\text { CACAGTCTTCTGAGTGGCAGTGAT (AS) }\end{array}$ & 60 & 20 \\
\hline
\end{tabular}

eNOS = endothelial nitric oxide synthase; GAPDH = glyceraldehyde-3-dehydrogenase; iNOS = inducible nitric oxide synthase; $S=$ sense; $A S=$ antisense.

Table 2. Comparisons of age, weight and sex variables between the groups with left ventricular ejection fraction (LVEF) $>60 \%$ and LVEF $<35 \%$.

\begin{tabular}{lccc}
\hline Variable & Descriptive statistic & LVEF $>60 \%$ & LVEF $<35 \%$ \\
\hline Age (years) & Median & 62.5 & 62.1 \\
& Minimum & 49.0 & 45.0 \\
& Maximum & 78.0 & 80.0 \\
Weight (kg) & Median & 81.1 & 79.3 \\
& Minimum & 59.0 & 62.0 \\
& Maximum & 121.0 & 107.0 \\
Sex & Female & 3 & 3 \\
& Male & 7 & 7 \\
\hline
\end{tabular}

There were no statistical differences between groups for age (Mann-Whitney test), weight (Mann-Whitney test) or sex (Fisher test). agarose gel containing $0.5 \mu \mathrm{g} / \mathrm{ml}$ ethidium bromide. The gel was subjected to ultraviolet light and photographed. Band intensities were measured using a software package (Kodak Digital Science, Eastman Kodak Company, New Haven, CT, USA) and the signals were expressed relative to the intensity of the GAPDH amplicon in each coamplified sample.

\section{Statistical analysis}

Multivariate analysis of variance was used to compare eNOS and iNOS activities and their gene expressions between groups $\mathrm{A}$ and B. Age and weight distributions between patients with and without heart failure were compared by the Mann-Whitney test. Sex differences were compared by the Fisher test. Pearson's correlation coefficients were calculated to determine the relation of eNOS and iNOS activity and expression with LVEF and functional class. A $\mathrm{P}$ value $<0.05$ was considered significant.

\section{Results}

The A group consisted of 10 patients, 7 males and 3 females, without heart failure and LVEF $>60 \%$. All patients were in functional class 0 of the New York Heart Association (NYHA). The B group consisted of 10 patients, 7 males and 3 females, with heart failure and LVEF $<35 \%$. In this group 3 patients were in functional class II, 4 in class III and 3 in class IV of NYHA. Patient characteristics are shown in Tables 2, 3, and 4.

\section{eNOS and iNOS activities}

eNOS activity was significantly lower in failing hearts than in non-failing hearts: 0.36 \pm 0.18 vs $1.51 \pm 0.31 \mathrm{pmol} \mathrm{mg}^{-1} \mathrm{~min}^{-1}$ $(\mathrm{P}<0.0001$; Figure 1A). In contrast, iNOS activity was significantly increased in failing hearts compared with non-failing hearts: 4.00 \pm 0.90 vs $1.54 \pm 0.65 \mathrm{pmol} \mathrm{mg}^{-1} \mathrm{~min}^{-1}$ 
$(\mathrm{P}<0.0001 ;$ Figure 1B).

\section{eNOS and iNOS expression}

eNOS expression was significantly lower in failing hearts than in non-failing hearts: $0.37 \pm 0.08$ vs $0.78 \pm 0.09$ absorbance cDNA ( $\mathrm{P}<0.0001$; Figure $2 \mathrm{~A})$. In contrast, iNOS expression was significantly increased in hearts with LVEF <35\% compared with hearts with LVEF $>60 \%: 2.19 \pm 0.27$ vs 1.43 \pm 0.13 absorbance cDNA $(\mathrm{P}<0.0001$; Figure $2 \mathrm{~B})$.

The results of RT-PCR assays for the detection of eNOS and iNOS expression measured in one patient of each group are shown in Figure 3 (see legend).

There were no statistically significant correlations between functional class and NOS activities or gene expression in either group $(\mathrm{P}>0.05)$.

The present study shows that activity and gene expression of eNOS in atrial tissue from patients with CAD were significantly lower in those with heart failure and LVEF $<35 \%$ than in those without heart failure and LVEF $>60 \%$. In contrast, iNOS activity and expression were significantly higher in patients with heart failure and $\mathrm{LVEF}<35 \%$ compared with non-failing hearts with LVEF $>60 \%$.

Table 3. Clinical and hemodynamic characteristics of patients with left ventricular ejection fraction $>60 \%$.

\begin{tabular}{lccccccccc}
\hline Patient & Sex & $\begin{array}{c}\text { Age } \\
\text { (years) }\end{array}$ & $\begin{array}{c}\text { Weight } \\
(\mathrm{kg})\end{array}$ & NYHA & $\begin{array}{c}\mathrm{HR} \\
(\mathrm{bpm})\end{array}$ & $\begin{array}{c}\mathrm{ABP} \\
(\mathrm{mmHg})\end{array}$ & $\begin{array}{c}\text { Creatinine } \\
(\mathrm{mg} / \mathrm{dl})\end{array}$ & $\begin{array}{c}\text { LVEF } \\
(\%)\end{array}$ & $\begin{array}{c}\mathrm{BMI} \\
\left(\mathrm{kg} / \mathrm{m}^{2}\right)\end{array}$ \\
\hline 1 & $\mathrm{M}$ & 56 & 96 & 0 & 90 & $130 / 80$ & 1.2 & 65 & 32 \\
2 & $\mathrm{M}$ & 63 & 121 & 0 & 84 & $120 / 80$ & 1.4 & 65 & 39 \\
3 & $\mathrm{M}$ & 65 & 73 & 0 & 80 & $120 / 80$ & 0.7 & 62 & 23 \\
4 & $\mathrm{M}$ & 62 & 45 & 0 & 84 & $110 / 70$ & 0.9 & 65 & 19 \\
5 & $\mathrm{M}$ & 78 & 77 & 0 & 60 & $130 / 80$ & 1.2 & 62 & 25 \\
6 & $\mathrm{M}$ & 58 & 72 & 0 & 72 & $130 / 80$ & 1.1 & 63 & 24 \\
7 & $\mathrm{M}$ & 58 & 93 & 0 & 76 & $120 / 80$ & 1.4 & 62 & 30 \\
8 & $\mathrm{~F}$ & 49 & 59 & 0 & 80 & $110 / 60$ & 1.1 & 65 & 23 \\
9 & $\mathrm{~F}$ & 73 & 60 & 0 & 80 & $90 / 60$ & 1.1 & 70 & 22 \\
10 & $\mathrm{~F}$ & 63 & 85 & 0 & 92 & $110 / 60$ & 0.8 & 67 & 31 \\
\hline
\end{tabular}

$\mathrm{ABP}=$ arterial blood pressure; $\mathrm{BMI}=$ body mass index; $\mathrm{HR}=$ heart rate; $\mathrm{LVEF}=$ left ventricular ejection fraction; NYHA = New York Heart Association Classification of Cardiac Heart Failure.

Table 4. Clinical and hemodynamic characteristics of patients with left ventricular ejection fraction $<35 \%$.

\begin{tabular}{cccccccccc}
\hline Patient & Sex & $\begin{array}{c}\text { Age } \\
\text { (years) }\end{array}$ & $\begin{array}{c}\text { Weight } \\
(\mathrm{kg})\end{array}$ & NYHA & $\begin{array}{c}\mathrm{HR} \\
(\mathrm{bpm})\end{array}$ & $\begin{array}{c}\text { ABP } \\
(\mathrm{mmHg})\end{array}$ & $\begin{array}{c}\text { Creatinine } \\
(\mathrm{mg} / \mathrm{dl})\end{array}$ & $\begin{array}{c}\text { LVEF } \\
(\%)\end{array}$ & $\begin{array}{c}\text { BMI } \\
\left(\mathrm{kg} / \mathrm{m}^{2}\right)\end{array}$ \\
\hline 1 & M & 66 & 81 & III & 100 & $83 / 67$ & 2.0 & 21 & 28 \\
2 & M & 77 & 97 & II & 88 & $90 / 60$ & 1.2 & 35 & 34 \\
3 & M & 62 & 70 & III & 90 & $110 / 70$ & 1.3 & 17 & 25 \\
4 & M & 80 & 55 & II & 92 & $130 / 80$ & 1.4 & 35 & 23 \\
5 & M & 45 & 88 & III & 98 & $110 / 70$ & 1.8 & 35 & 30 \\
6 & M & 55 & 83 & II & 94 & $90 / 55$ & 1.3 & 35 & 28 \\
7 & F & 46 & 65 & IV & 98 & $90 / 60$ & 1.4 & 23 & 22 \\
8 & F & 57 & 68 & IV & 90 & $90 / 60$ & 1.6 & 20 & 24 \\
9 & M & 78 & 107 & III & 88 & $90 / 50$ & 1.9 & 35 & 34 \\
10 & F & 47 & 62 & IV & 104 & $130 / 80$ & 3.0 & 26 & 26 \\
\hline
\end{tabular}

$\mathrm{ABP}=$ arterial blood pressure; $\mathrm{BMI}=$ body mass index; $\mathrm{HR}=$ heart rate; $\mathrm{LVEF}=$ left ventricular ejection fraction; NYHA = New York Heart Association Classification of Cardiac Heart Failure. 


\section{Discussion}

Although the importance of NO for the regulation of vasomotor tone has been established, the physiological role of NO in cardiac function and structure remains incompletely understood. Removal of the endocardium or endothelium modulates cardiac contraction, suggesting that the NO released from endothelial and endocardial cells modulates cardiac contraction (25).

Ischemia elicits a variety of adaptive responses at the tissue, cellular and molecular
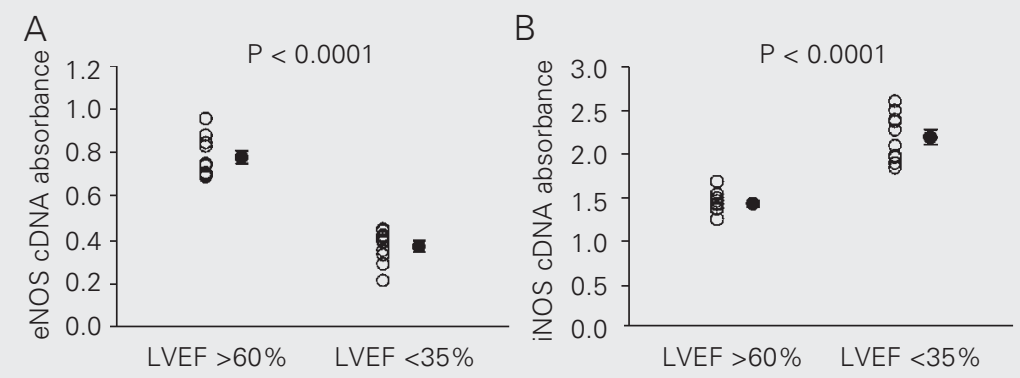

Figure 2. Individual values of (A) endothelial (eNOS) and (B) inducible nitric oxide synthase (iNOS) activity in the right atrial appendage of patients in the groups with left ventricular ejection fraction (LVEF) $>60 \%$ and LVEF $<35 \%$, reported as relative cDNA absorbance. The symbols to the right of individual values are the mean \pm SEM. $N=10$ patients in each group.

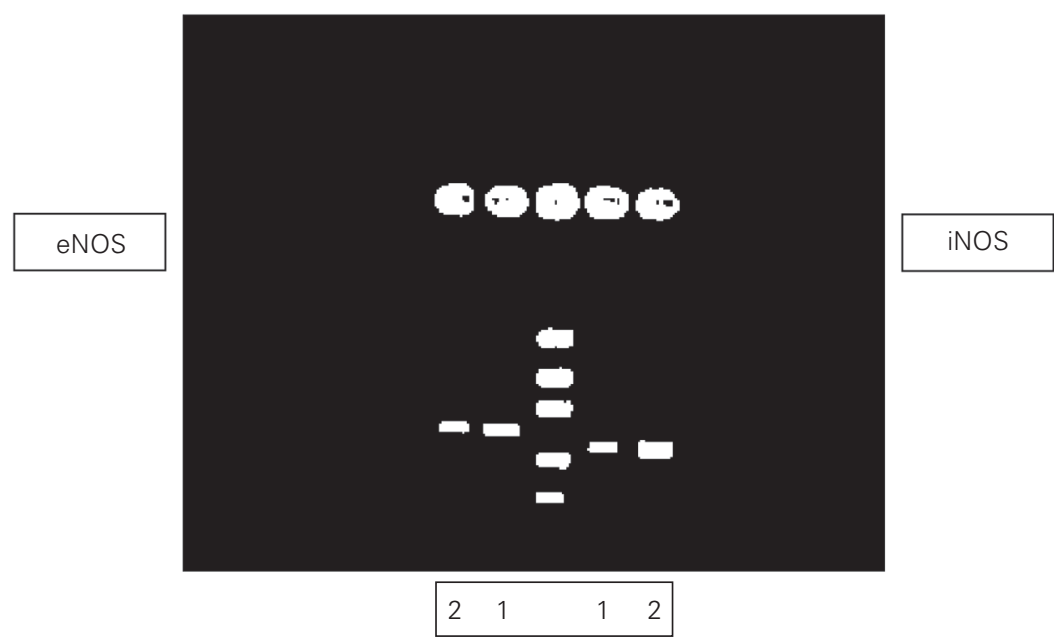

Figure 3. Representative RT-PCR assay for the detection of endothelial nitric oxide synthase (eNOS) and inducible nitric oxide synthase (iNOS) expression. The lower expression of eNOS in a patient with heart failure (number 2) can be seen on the left side; on the right, iNOS expression is higher in the patient with heart failure (number 2) than in the patient without heart failure (number 1). The line in the middle represents the standard values. levels. A physiological response to ischemia requires the existence of a signal transduction system which should be linked or coupled to an $\mathrm{O}_{2}$ sensor (26). The results of the present study provide evidence that heart failure probably induces iNOS gene expression in cardiac tissue from patients with ischemic cardiomyopathy. Unlike eNOS, iNOS is not usually expressed in healthy tissues (27). One of the difficulties in studying diseased human myocardium is the absence of a readily avaliable source of normal control tissue. Our knowledge about iNOS levels in normal cardiac tissue derives from studies that investigated iNOS mRNA expression in heart donors (28) and that revealed no expression or activity of iNOS. In the present study iNOS activity and expression in patients with non-failing hearts were surprisingly high and may have been related to $\mathrm{CAD}$ or to cardiothoracic surgery itself.

In addition, the present study provides evidence that eNOs and iNOS activity and gene expression are related to ventricular function. de Belder et al. (19) obtained similar results, but only for nonischemic dilated cardiomyopathy. Heymes et al. (27) found a linear correlation between LVEF and eNOS expression, also in patients with nonischemic dilated cardiomyopathy. On the other hand, Drexler et al. (28) reported a higher activity and expression of iNOS in patients with heart failure due to several etiologies. These investigators used explanted hearts from donors as matched controls, and did not find any iNOS activity in such hearts. A possible explanation for this result may be the abnormal conditions associated with brain death, ventilation, and explantation of the donor's heart. Our results about iNOS activity and expression agree with previous studies $(18,27,28)$ although our samples were taken from the right atrium.

We also investigated a possible correlation between functional class and eNOS and iNOS activity levels or gene expression, but found no correlations. In a previous study 
(16) it was demonstrated that patients with NYHA II presented higher iNOS expression than those with normal functional class. On the other hand, Satoh et al. (18) showed that iNOS expression was related predominantly to LVEF and not to functional class.

Comparison between eNOS activity and gene expression in both groups supports the idea that eNOS is down-regulated as LVEF decreases, in agreement with data reported by Heymes et al. (27) who investigated heart failure patients with LVEF lower than $40 \%$.

Furthermore, the right atrium may not be the ideal sampling site for biopsies, because its cells are not well localized to sense shear stress induced by pulsatile flow. On the other hand, right atrium cells are well localized to act as $\mathrm{O}_{2}$ sensors, especially cells of the endocardium, which may be particularly suited to sensing changes in preload.

$\mathrm{NO}$ and cyclic guanosine monophosphate (cGPM) induce a concentration-dependent biphasic contractile response: low NO doses cause a positive inotropic response, while higher doses cause a negative inotropic response (28). Increased iNOS activity probably represents the pathway for increased NO production in heart failure, which would be an attempt to counterbalance the vasoconstrictor state found in patients with reduced LVEF. In a previous study (29) we analyzed the relation between hypoxia and NOS in children with congenital heart defects and showed that iNOS activity and gene expression are up-regulated in right atrial hypoxic tissue compared with nonhypoxic tissue. Thus, it is possible that both hypoxic and ischemic hearts share a com- mon adaptive mechanism, namely increased NO production via iNOS. In addition, NO acts as a bifunctional regulator of apoptosis. Physiologically relevant NO levels seem to suppress the apoptotic pathway, while NO levels may overwhelm cell protective mechanisms and exert proapoptotic and cytotoxic effects in patients with heart failure (30-32). Indeed, excessive NO production secondary to the induction of iNOS in failing cardiac tissue would be expected to depress cardiac contraction, as observed in septic shock $(33,34)$. This idea is further supported by the observation of high plasma and tissue levels of various cytokines, such as TNF- $\alpha$, known to induce iNOS (35-40). Since NO was not assessed in the present study, its possible relation to other phenomena occurring during heart failure, including apoptosis and cytokine release, is speculative.

\section{Study limitations}

The biochemical conversion of L-arginine to L-citrulline assay as a measure of NOS activity has its limitations, and our data should be interpreted carefully; however, the simultaneous indications of the direction of the change of NOS gene expression and chemical activity of both NOS forms add confidence to the measurements.

We conclude that in the present study iNOS gene expression and activity were increased in cardiac tissue from patients with heart failure and presumably this phenomenon led to increased NO bioavailability. This may represent an important adaptive mechanism in heart failure.

\section{References}

1. Moncada S \& Higgs A (1993). The L-arginine-nitric oxide pathway. New England Journal of Medicine, 329: 2002-2012.

2. Furchgott RF \& Zawadzki JV (1980). The obligatory role of endothelial cells in the relaxation of arterial smooth muscle by acetylcholine. Nature, 288: 373-376.

3. Palmer RMJ, Ferrige AG \& Moncada S (1987). Nitric oxide release accounts for the biological activity of endothelium-derived relaxing factor. Nature, 327: 415-423.

4. Moncada S, Higgs A \& Furchgott R (1997). XIV International union of pharmacology nomenclature in nitric oxide research. Pharmacological Reviews, 49: 137-142.

5. Laurindo FRM \& Leite PF (2003). Síntese do óxido nítrico. In: da Luz 
$\mathrm{PL}$, Laurindo FRM \& Chagas ACP (Editors), Endotélio e Doenças Cardiovasculares. Vol. 4. Editora Atheneu, São Paulo, SP, Brazil, 4351.

6. Papapetropoulos A, Rudic RD \& Sessa WC (1999). Molecular control of nitric oxide synthases in the cardiovascular system. Cardiovascular Research, 43: 509-520.

7. Zweier JL, Wang P \& Samouilov A (1995). Enzyme-independent formation of nitric oxide in biological tissues. Nature Medicine, 8: 804-809.

8. Wilcox JN, Subramanian RRCL \& Sundell CL (1997). Expression of multiple isoforms of nitric oxide synthase in normal and atherosclerotic vessels. Arteriosclerosis, Thrombosis, and Vascular Biology, 17: 2479-2488.

9. Nadaud S \& Sobrier F (1996). Molecular biology and molecular genetics of nitric oxide synthase genes. Clinical and Experimental Hypertension, 18: 113-143.

10. Forstemann U, Closs El \& Pollock JS (1994). Nitric oxyde synthase isozymes: characterization, purification, molecular cloning and functions. Hypertension, 23 (Part 2): 1121-1131.

11. Brutsaert DL, Meulemans AL, Sipido KR \& Sys SU (1988). Effects of damaging the endocardial surface on the mechanical performance of isolated cardiac muscle. Circulation Research, 62: 357-366.

12. Finkel MS, Oddis CV, Jacob TD, Watkins SC, Hattler BG \& Simmons $R L$ (1992). Negative inotropic effects of cytokines on the heart mediated by nitric oxide. Science, 257: 387-389.

13. Schulz R, Nava E \& Moncada S (1992). Induction and potential biological relevance of a $\mathrm{Ca}^{2+}$-independent nitric oxide synthase in the myocardium. British Journal of Pharmacology, 105: 575-580.

14. de Belder AJ, Radomski MW, Why HJ, Richardson PJ \& Martin JF (1995). Myocardial calcium-independent nitric oxide synthase activity is present in dilated cardiomyopathy, myocarditis, and portpartum cardiomyopathy but not in ischaemic or valvar heart disease. British Heart Journal, 74: 426-429.

15. Thoenes M, Forstermann U \& Tracey WR (1996). Expression of inducible nitric oxide synthase in failing and non-failing human heart. Journal of Molecular and Cellular Cardiology, 28: 165-169.

16. Haywood GA, Tsao PS \& Von Der Leyen HE (1996). Expression of inducible nitric oxide synthase in human failing heart. Circulation, 93: 1087-1094.

17. Habib FM, Springal DR \& Davies GJ (1996). Tumour necrosis factor and inducible nitric oxide synthase in dilated cardiomyopathy. Lancet, 347: 1151-1155.

18. Satoh M, Nakamura M \& Tamura G (1997). Inducible nitric oxide synthase and tumor necrosis factor-alpha in myocardium in human dilated cardiomyopathy. Journal of the American College of Cardiology, 29: 716-724

19. de Belder AJ, Radomski M, Why H, Richardson PJ \& Moncada S (1993). Nitric oxide synthase activities in human myocardium. Lancet, 341: 84-85.

20. Stein B, Eschenhagen T \& Rudiger J (1998). Increased expression of constitutive nitric oxide synthase III, but not inducible nitric oxide synthase II, in human heart failure. Journal of the American College of Cardiology, 32: 1179-1186.

21. Nissen SE, Elion JL, Grayburn P, Booth DC, Wisenbaugh TW \& DeMaria AN (1987). Determination of left ventricular ejection fraction by computer densitometric analysis of digital subtraction angiography: experimental validation and correlation with area-length methods. American Journal of Cardiology. 59: 675-680.
22. McKee M, Scavone C \& Nathanson JA (1994). Nitric oxide, cGMP, and hormone regulation of active sodium transport. Proceedings of the National Academy of Sciences, USA, 91: 12056-12060.

23. Bradford M (1976). A rapid and sensitive method for the quantitation of microgram quantities of protein utilizing the principle of protein-dye binding. Annals of Biochemistry, 72: 248-254.

24. Teng KS, Murthy JF \& Kuemmerle JR (1998). Expression of endothelial nitric oxide synthase in human and rabbit gastrointestinal smooth muscle cells. American Journal of Physiology, 275: G342G351.

25. Winegrad S (1997). Endothelial cell regulation of contractility of the heart. Annual Review of Physiology, 59: 505-525.

26. Michel T \& Feron O (1997). Nitric oxide synthases: which, where, how, and why? Journal of Clinical Investigation, 100: 2146-2152.

27. Heymes C, Vanderheyden M \& Bronzwaer JGF (1999). Endomyocardial nitric oxide synthase and left ventricular preload reserve in dilated cardiomyopathy. Circulation, 99: 3009-3016.

28. Drexler H, Kastner S \& Strobel A (1998). Expression and functional significance of inducible nitric oxide synthase in the failing human heart. Journal of the American College of Cardiology, 32: 955-963.

29. Ferreiro CR, Chagas ACP, Carvalho MHC, Dantas AP, Jatene MB, Souza LCB \& da Luz PL (2001). Influence of hypoxia on nitric oxide synthase activity and gene expression in children with congenital heart disease. Circulation, 103: 2272-2276.

30. Kim YM, Bombeck CA \& Billiar TR (1999). Nitric oxide as a bifunctional regulator of apoptosis. Circulation Research, 84: 253-256.

31. Ing DJ, Zang J \& Dzau VJ (1999). Modulation of cytokine-induced cardiac myocyte apoptosis by nitric oxide, Bak, and Bcl-x. Circulation Research, 84: 21-33

32. Pinsky D, Cai B \& Yang X (1994). Nitric oxide-dependent killing of cardiac myocytes by adjacent macrophages. Circulation, 90 (Suppl I): l-192.

33. Price S, Anning PB, Mitchell JA \& Evans TW (1999). Myocardial dysfunction in sepsis: mechanisms and therapeutic implications. European Heart Journal, 20: 715-724.

34. Ullrich R, Scherrer CM \& Bloch KD (2000). Congenital deficiency of nitric oxide synthase 2 protects against endotoxin-induced myocardial dysfunction in mice. Circulation, 102: 1440-1446.

35. Kasai K, Hattori $Y$ \& Banba N (1997). Induction of tetrahydrobiopterin synthesis in rat cardiac myocytes: impact on cytokine-induced NO generation. American Journal of Physiology, 273: H665-H672.

36. Sasayama S, Matsumori A \& Kihara Y (1999). New insights into the pathophysiological role for cytokines in heart failure. Cardiovascular Research, 42: 557-564

37. Torre AG, Kapadia S \& Lee J (1996). Tumor necrosis factor-alpha and tumor necrosis factor receptors in the failing human heart Circulation, 93: 704-711

38. Oral H, Dorn 2nd GW \& Mann DL (1997). Sphingosine mediates the immediate negative inotropic effects of tumor necrosis factor-alpha in the adult mammalian cardiac myocyte. Journal of Biological Chemistry, 272: 4836-4842.

39. Kubota T, McTiernan CF \& Frye CS (1997). Dilated cardiomyopathy in transgenic mice with cardiac-specific overexpression of tumor necrosis factor-alpha. Circulation Research, 81: 627-635.

40. Kalra D, Baumgarten G \& Dibbs Z (2000). Nitric oxide provokes tumor necrosis factor-alpha expression in adult feline myocardium through a cGMP-dependent pathway. Circulation, 102: 1302-1307. 